\title{
COMPARISON OF THE EFFECTIVENESS OF GIVING BINAHONG LEAF (Anredera cordifolia (Ten) Steenis) AND PAPAYA LEAF (Carica papaya) ON SKIN WOUND HEALING IN WHITE RAT (Rattus novergicus)
}

\author{
Givenchy A Winarjo ${ }^{1)}$, Fransiscus Arifin ${ }^{2)}$, Dave G Oenarta ${ }^{3}$
}

\begin{abstract}
Introduction: The incidence of acute and chronic injuries increases every year. Most injuries in the world population, as many as $48 \%$, are caused by trauma or surgery. the highest incidence of wounds in the world based on the etiology was from surgery, which was 110.30 million cases. One of the handlings of wounds on the skin can be done by giving herbal medicines, which can be easily accessed by the public, such as binahong leaves and papaya leaves.

Purpose: To analyze the effectiveness of giving $40 \%$ binahong leaf extract cream and $40 \%$ papaya leaf extract cream on the wound distance in the white rat wound healing process.

Method: this study is an experimental study with post-test only control group design approach. The sampling technique used in this study was a random sampling method where the number of samples was calculated using the Federer formula, with a total sample of 28 white rats. The distance of the wound was measured using a micrometer.

Results: Twenty-eight wound distance on rats were measured as subjects of the study and then treated with binahong leaf extract cream and papaya leaf extract cream, then the wound distance of each treatment was measured using a micrometer. According to the results, $40 \%$ binahong leaf extract cream and $40 \%$ papaya leaf extract cream showed better effectiveness in reducing the wound distance of white rat incision than the negative control group (cream base) and positive control group (gentamicin ointment). According to the Mann Whitney test comparing the P1 group (40\% binahong leaf extract cream) and P2 (40\% papaya leaf extract cream), p-value $>0.05$, which is 0.543 , which means that $\mathrm{P} 1$ has no significant mean difference with $\mathrm{P} 2$.
\end{abstract}

Conclusion: There was no significant difference in effectiveness between the treatment of $40 \%$ binahong leaf extract cream and $40 \%$ papaya leaf extract cream.

Keyword: Wounds incision, wound distance, cream, 40\% binahong leaf extract, $40 \%$ papaya leaf extract cream.

\footnotetext{
${ }^{1)}$ Student of Faculty of Medicine, Widya Mandala Surabaya Catholic University Indonesia, Jl. Kalisari Selatan No.1 Surabaya Email: angelwinarjo@gmail.com

${ }^{2)}$ Surgery Department, Faculty of Medicine, Widya Mandala Surabaya Catholic University Indonesia, Jl. Kalisari Selatan No.1 Surabaya

${ }^{3)}$ Dermatovenereology Department, Faculty of Medicine, Widya Mandala Surabaya Catholic University Indonesia, J1. Kalisari Selatan No.1 Surabaya
} 


\section{INTRODUCTION}

Injury is a condition of damaged body tissue, which can occur due to surgery, trauma, gunfire, chemicals, sharp or blunt objects, electric shock, etc ${ }^{1}$. Every year, there is an increase in the incidence of acute and chronic wounds. Most of the injuries that occur in the world population are caused by surgery or trauma (as much as $48.00 \%)^{2}$. All people can experience injuries. Injuries to the skin can cause discomfort such as pain, if the wound is left and not treated, it can interfere with phase of wound healing and cause inhibition of wound healing, and complications such as infection, emergence of hypertrophic scarring, brush matrix, and keloid. ${ }^{3,4}$

Wound healing is an attempt to repair damaged skin. Physiologically, there are four phases in wound healing: hemostasis, inflammation, proliferation, and maturation ${ }^{3}$. Standard treatment of skin lesions includes primary and secondary wound healing. In secondary wound healing, usually, no treatment was given to the wound. The wound heals by itself or is given anti-inflammatory, antiseptic antibiotics (such as bacitracin, fusidic acid, mupirocin, and gentamicin) with topical herbal medicines. While in primary wound healing, the edges of the wound can be met by stitching, but for small or medium cuts, wound suturing is considered less economical because the wound can heal by itself without stitching if there is no infection.

People tend to prefer herbal medicines to other treatments because treatment with herbal medicines is more accessible, cheaper, less toxic, less side effects, and easier to use ${ }^{6}$. Binahong leaves contain bioactive compounds such as flavonoids and saponins. Saponin compounds are antiseptic. Saponins are also known to have the ability to increase the number of fibroblast cells and also stimulate the formation of type I collagen, which is helpful in wound healing ${ }^{7}$. Flavonoid compounds found in binahong leaves are capable of being antiinflammatory. In addition, the content of vitamin $\mathrm{C}$ in the leaves of binahong is useful as an antioxidant. It can influence the formation of collagen, which is useful in wound healing ${ }^{8}$.

One of the plants containing saponins, flavonoids, alkaloids, and polyphenols is papaya leaves (Carica papaya L). papain enzyme in the papaya leaves can increase granulation tissue formation in the proliferation phase of the wound healing process and reduce bacterial infections. Besides, the beta carotene content in papaya leaves is useful as an antioxidant that acts to neutralize 
free radicals and neutralize the results of neutrophil phagocytosis in bacteria ${ }^{9,10}$.

Previous studies have shown that binahong leaf extract at a concentration of $40 \%$ is beneficial for wound healing. In contrast, in other studies, papaya leaf extract with a concentration of $100 \%$ has been shown to accelerate wound healing. Still, the difference in the effectiveness of giving binahong leaf extract (Anredera cordifolia) and papaya leaf extract (Carica papaya L.) on wound length in wound healing of white rats (Rattus norvegicus) is not certainly known, therefore, this research is focused on comparing the effectiveness of giving binahong leaf extract cream (Anredera cordifolia), and papaya leaves extract cream (Carica papaya L.) at concentrations $40 \%$, which one is the most useful for topical wound healing through measurement of wound length in healing white rats (Rattus norvegicus) $)^{5,11}$.

\section{METHOD}

This research was conducted experimentally using post-test-only control group design method. This study used white rats (Rattus norvegicus) male wistar strain and grouped into four groups, two control groups, and two treatment groups. The sampling technique in this study was by simple random sampling.
The population of this research was white rats (Rattus norvegicus) male wistar strain. The number of samples from this study was calculated using the Federer formula. ${ }^{12}$ Based on the results of these calculations, each group was obtained as many as six rats. It is possible that the experimental animals died during the study, so each group was added $10 \%$ of the amount, which is one experimental animal in each group. So each group consists of 7 white rats. Total sample size $=4$ groups $\mathrm{x}$ 7 white rats $=28$ white rats.

Inclusion criteria in this study are white rats (Rattus norvegicus) male, Wistar strain, 1.5-3 months, weighing 200250 grams, no anatomical abnormalities, active activity, and no injuries or infections, for exclusion criteria: there are skin abnormalities or injuries before the treatment, and the drop out criteria are the rats appearing sick (mice movement appears less active), there is an infection in the wound, or die during the process of adaptation or treatment.

In this study, the data collection procedure was the preparation of experimental animals, which are white rats (Rattus novergicus) held in cages with a size of $17.5 \times 23.75 \times 17.5 \mathrm{~cm}$ made of plastic tubs and given a cage cover made of wire. Rats were kept and adapted for a week in a cage and given the same pellet food and 
drink. After being adapted for one week, rats are ready to be treated. Binahong leaves and papaya leaves were purchased and determined at Materia Medica Batu, Lahor street no.87, Pesanggrahan, Batu sub-district, Batu city of East Java Indonesia 65313. The making of $40 \%$ Binahong Leaf Extract Cream and 40\% Papaya Leaf Extract Cream was carried out at the Natural Materials Laboratory of the Faculty of Pharmacy, Widya Mandala University, Surabaya.

Incision wounds on white rats were made at the Educational Animal Hospital Airlangga University.

Before being given treatment, a sedative action was carried out on rats with a mixture of 1:1 xylazine and ketamine, with a dose of $10 \mathrm{mg}$ xylazine and $50 \mathrm{mg}$ of ketamine $(0.1 \mathrm{cc} / \mathrm{g}$ body weight of rats $)$. After that, the fur on the backs of rats was shaved $3 \times 3 \mathrm{~cm}$, and that area disinfected using $10 \%$ poodone iodine. Then an incision wound is made with a scalpel, which is two centimeters long with a wound depth of $0.2 \mathrm{~cm} .{ }^{13}$

After the incision, group 1 rats (P1), as many as seven rats, were given binahong leaf extract, which was smeared on the wound using cotton buds. Then group 2 mice, P2, and seven rats were given papaya leaf extract by applying it to the wound using cotton buds. Group 3 rats,
$\mathrm{KK} 1$, consisting of seven mice, were given a cream base by laying it on the wound using cotton buds. Whereas group 4 rats, KK2, composed of seven mice, were assigned gentamicin ointment. Treatment on rats was carried out for fourteen days with two treatments each day, in the morning and evening, then incision wounds in all four groups were bandaged so that the wound was not contaminated. Measurement of the wound length (macroscopic) was done with a micrometer before giving treatment to the groups.

\section{RESULTS}

The comparison result of wound length between groups is P2 group, the group given papaya leaf extract cream $40 \%$ had the highest reduction in wound length. Then the second highest wound length reduction was group $\mathrm{P} 1$ by giving binahong leaf extract cream $40 \%$, then in the third position was P3 group given a cream base and the fourth is group P4 given gentamicin.

The results of the calculation of the average length of incision wounds obtained: the average value of wound length from the group that was given $40 \%$ binahong leaf extract cream was $1.195 \mathrm{~cm}$, then the wound length of the treatment group with papaya leaf extract cream $40 \%$ was $1.145 \mathrm{~cm}$, the wound length of the 
negative control group treated with a cream base was $1,485 \mathrm{~cm}$, then the length of the wound of the positive control group that was treated with gentamicin was 1,670 $\mathrm{cm}$.

In this study, the hypothesis test was carried out using Kruskal Wallis test, followed by a post hoc test. After the Kruskal-Wallis test was carried out, the Mann-Whitney test continued to find significant differences between the two variables. It can be seen that $\mathrm{P} 1$ and $\mathrm{P} 2$ do not have a significant mean difference because the value of $p>0.05$ is equal to 0.543.Comparison between $\mathrm{P} 2$ and $\mathrm{P} 3$ also does not have a significant mean difference because of the p-value of 0.147. In comparison, $\mathrm{P} 1$ and $\mathrm{P} 4$ have a significant mean difference because the value of $\mathrm{p}<0.05$ is equal to $0.012, \mathrm{P} 2$ and P4 have a significant mean difference because of the p-value of 0.024 . Then for $\mathrm{P} 2$ and P4, the mean difference is also significant because it has a p-value of 0,000. Then, P3 and P4 has a significant mean difference because the p-value is 0.037 , which means $\mathrm{p}<0.05$.

\section{DISCUSSION}

The results and analysis of incision wound distance data in the 4 groups stated that the average length of incision wounds in group P1 (treatment group with binahong leaf extract cream 40\%) was $1.1954 \pm 1.222928$, group P2 (treatment group with papaya leaf extract cream $40 \%$ ) was $1.1452 \pm 1.09528$, group P3 (negative control group with cream base) was 1.4854 \pm 0.98399 , and group P4 (positive control group with gentamicin ointment) $1.6701 \pm$ 1.06456. This shows that papaya leaf extract cream $40 \%$ has the highest reduction in wound length. The secondhighest reduction in wound length is in the group given binahong leaf extract cream $40 \%$. The third is the negative control group with a cream base, and the fourth is the positive control group with gentamicin ointment.

Active ingredients such as saponins, flavonoids, and alkaloids found in papaya leaves and binahong leaves can assist the wound healing phases. In addition to its role in the inflammatory phase as an antiseptic, in the proliferation phase, saponins can increase the process of angiogenesis, increase the number of fibroblast cells and stimulate the formation of type I collagen. The flavonoid content also plays a role in the wound healing phase as an antiseptic, anti-inflammatory, and antioxidant. In addition to the proliferation phase, the flavonoid content can help increase vascularity. ${ }^{11,14,15}$ alkaloid content plays a role in the inflammatory phase as an antiseptic. ${ }^{15}$ The 
reduction in wound length of the group given papaya leaf extract cream $40 \%$ is higher than the treatment group with binahong leaf extract cream $40 \%$. This is possibly due to the content of the papain enzyme in papaya leaves which is not possessed by extracts of other ingredients.

The papain enzyme acts as an antiinflammatory, accelerating the work of macrophages in the inflammatory phase. Besides that, in the proliferation phase, the enzyme papain also plays a role in the formation of granulation tissue, increasing the contraction of the wound edges and bringing the wound edges together. ${ }^{16,17}$

In this study, the Mann-Whitney test results comparing the treatment group with $40 \%$ binahong leaf extract cream and the group treatment with papaya leaf extract $40 \%$, obtained $p>0.05, p=0.543$. This means they were not significantly different because the active ingredient in both is almost the same. Therefore, their effectiveness in helping the healing process of incision wounds in white rats was not much different.

In this study, base cream has the best effectiveness in incision wound healing after papaya leaf extract cream $40 \%$ and binahong leaf extract cream $40 \%$. Base cream shows better incision wound healing effectiveness than gentamicin ointment. This is contrary to the research conducted by Miryam et al. (2014), who explained that the use of gentamicin cream could accelerate incision wound healing in rabbits infected with Staphylococcus aureus bacteria better than base cream. This is suspected because there are different topical medication forms, antibiotic resistance, allergic reactions, and disruption of normal flora. The different types of topical medication form used to affect the absorption of the skin, in this case, the form of gentamicin used in this study is an ointment which is a preparation with a semi-solid fat base material that is not suitable for use in hairy areas, folds and acute inflammation, whereas cream preparations are more moisturizing, more easily applied evenly, easier penetration on the skin, and is more suitable for use in lesions with hairy areas, intertriginous areas, and superficial and dry lesions. ${ }^{18,19}$

\section{CONCLUSION}

1. The application of binahong leaf extract cream affects the wound length in the healing process of incision wounds.

2. The application of papaya leaf extract cream affects the wound length in the healing process of incision wounds.

3. There is no significant difference in effectiveness between giving $40 \%$ binahong leaf extract cream and $40 \%$ 
papaya leaf extract cream in incision wound healing.

\section{REFERENCES}

1. Hoediyanto $\mathrm{H}$, Apuranto $\mathrm{H}$, Kusuma SE, Solichin HS, Yudianto A, Mutahal $\mathrm{H}$, et al. Ilmu Kedokteran Forensik dan Medikolegal. 8th ed. Hoediyanto, Apuranto H, editors. Surabaya: Departeman Ilmu kedokteran Forensik dan Medikolegal Fakultas Kedokteran Universitas Airlangga Surabaya; 2012.

2. Huda N, Ferbriyanti E, Laura D De. Edukasi Berbasis Nutrisi dan Budaya

3. Rachmawati S. Study Makroskopi, Mikroskopi dan Skrining Fitokimia Daun Aredera cordifolia (Ten.) Steenis. [Surabaya]: Airlangga; 2007.

4. Gauglitz GG, Korting HC, Pavicic T, Ruzicka T, Jeschke MG. Hypertrophic Scarring and Keloids: Pathomechanisms and Current and Emerging Treatment Strategies. Mol Med. 2011;17(1-2):113-25

5. Nasution AAM, Batubara DE. Perbandingan Efektifitas Ekstrak Daun Pepaya (Carica papaya) 100\% dan Gentamisin Krim 0,1\%
Terhadap Ketebalan Epitel Pada Luka Sayat Tikus Wistar (Rattus Norvegicus). 2015;03(01):18-31

6. Kaur G, Utami NV, Usman HA. Effect of Topical Application of Binahong [Anredera cordifolia ( Ten .) Steenis] Leaf Paste in Wound Healing Process in Mice. Althea Med J. 2014;1(1):6-11.

7. Astuti SM, Sakinah A.M M, Andayani B.M R, Risch A. Determination of Saponin Compound from Anredera cordifolia (Ten) Steenis Plant (Binahong) to Potential Treatment for Several Diseases. J Agric Sci. 2011;3(4):224-32

8. Novriansyah R. Perbedaan Kepadatan Kolagen Disekitar Luka Insisi Tikus Wistar yang Dibalut Kasa Konvensional dan Penutup Oklusif Hidrokoloid Selama 2 dan 14 Hari. [Semarang]: Diponegoro; 2008

9. Yahya M. Khasiat Daun Pepaya Untuk Penderita Kanker. Novieta N, editor. Jakarta: Dunia Sehat; 2012

10. Septiningsih E. Efek Penyembuhan Luka Bakar Ekstrak Etanol 70\% Daun Pepaya ( Carica papaya L .) Dalam Sediaan Gel pada Kulit Punggung Kelinci New Zealand. 
[Surakarta]: Muhammadiyah

Surakarta; 2008.

11. Paju N, Yamlean PVY, Kojong N. Uji Efektivitas Salep Ekstrak Daun Binahong (Anredera cordifolia (Ten.) Steenis) pada Kelinci (Oryctolagus cuniculus) yang Terinfeksi Bakteri Staphylococcus aureus. Pharmacon J Ilm Farm UNSRAT. 2013;2(01):2302-493

12. Federer WT. Experimental Design Theory and Application. New Delhi: Calcutta Oxford \& IBH; 1967.

13. Rupina W, Trianto HF, Fitrianingrum I. Efek Salep Ekstrak Etanol $70 \%$ daun Karamuting terhadap Re-epitelisasi Luka Insisi Kulit Tikus Wistar. 2016;4(1):2630.

14. Acar T, Tcylidiz R, Vahapogxlu H, Karakay AS, Aydin R. Efficansy of Micronized Flavonoid Fraction on Healing in Thermally Injured Rat. Amal Burn Fire Disasters [Internet]. 2002;15(1). Available from: http://www.medbc.com/annals/revie w/vol_15/num_1/text/vol15n1p38.a $\mathrm{sp}$

15. PI GM, Nurdiana, Utami YW. The Effectiveness of Binahong Hydrogel ( Anredera cordifolia ( Ten ) Steenis
) to Reduce Macrophages Number in Proliferation Phase of Wound on Hyperglycemia Rats ( Rattus norvegicus ) Wistar Strain. Maj Kesehat FKUB. 2015;2(1):2940.16. Ansel Howard C. Pengantar Bentuk Sediaan Farmasi. Jakarta: UI Press; 1989

16. Mucio M, Medeiros M De, Isaac C, Altran SC, Nicolosi JT, Jr CA, et al. Study of The Effectiveness of Papain in Wound Healing and Specific Approach to Its Application in Patients With Venous Ulcers : A Systematic Review. Adv Plast Reconstr Surg. 2018;2(2):183-7.

17. Ramadhian MR, Widiastini AA. Kegunaan Ekstrak Daun Pepaya (Carica papaya) Pada Luka. J Agromedicine. 2018;5(1):513-7.

18. Yanhendri, Yenny SY. Berbagai Bentuk Sediaan Topikal dalam Dermatologi. Cermin Dunia Kedokt. 2012;39(6):423-30.

19. Ansel Howard C. Pengantar Bentuk Sediaan Farmasi. Jakarta: UI Press; 1989. 